\title{
Phytopathology"
}

\section{Current Status of Fusarium oxysporum Formae Speciales and Races}

\author{
V. Edel-Hermann ${ }^{\dagger}$ and C. Lecomte
}

Agroécologie, AgroSup Dijon, INRA, University of Bourgogne Franche-Comté, F-21000 Dijon, France.

Accepted for publication 19 November 2018.

\begin{abstract}
The Fusarium oxysporum species complex includes both plant pathogenic and nonpathogenic strains, which are commonly found in soils. F. oxysporum has received considerable attention from plant pathologists for more than a century owing to its broad host range and the economic losses it causes. The narrow host specificity of pathogenic strains has led to the concept of formae speciales, each forma specialis grouping strains with the same host range. Initially restricted to one plant species, this host range was later found to be broader for many formae speciales. In addition, races were identified in some formae speciales, generally with cultivar-level specialization. In 1981, Armstrong and Armstrong listed 79 F. oxysporum formae speciales and mentioned races in 16 of them. Since then, the known host range of $F$. oxysporum has considerably increased, and many new formae speciales and races have been identified. We carried out a comprehensive search of the literature to propose this review of F. oxysporum formae speciales and races. We recorded 106 well-characterized formae speciales, together with 37 insufficiently documented ones, and updated knowledge on races and host ranges. We also recorded 58 plant species/genera susceptible to $F$. oxysporum but for which a forma specialis has not been characterized yet. This review raises issues regarding the nomenclature and the description of $F$. oxysporum formae speciales and races.
\end{abstract}

Keywords: diversity, forma specialis, host specificity, host range, pathogenicity, race, root rot, vascular wilt.

The Fusarium oxysporum Schlechtend. species complex is comprised of soilborne fungi found in cultivated and uncultivated soils worldwide under various climates (Burgess 1981; Joffe and Palti 1977; Kommedahl et al. 1988; Mandeel et al. 1995). This species complex includes plant pathogens, human pathogens, and many nonpathogens. Pathogenic strains are morphologically indistinguishable from nonpathogenic strains. F. oxysporum displays high functional and genetic diversity (Kistler 1997; Nelson et al. 1981; O'Donnell et al. 2009; Steinberg et al. 2016). Evidence of its diversity lies in its impressive plant host range, which includes both dicots (e.g., bean, carnation, and tomato) and monocots (e.g., banana, orchids, and palms). Pathogenic F. oxysporum can affect perennial and annual plants, including mostly land-based, but also aquatic plants (e.g., lotus). From a practical point of view, pathogenic $F$. oxysporum strains cause wilts or root and crown rots on economically important field crops (banana, cotton, soybean),

${ }^{\dagger}$ Corresponding author: V. Edel-Hermann; E-mail: veronique.edel-hermann@inra.fr Authors contributed equally to the writing of this review.

*The $e$-Xtra logo stands for "electronic extra" and indicates that three supplementary files are published online.

This article is in the public domain and not copyrightable. It may be freely reprinted with customary crediting of the source. The American Phytopathological Society, 2019. many market garden crops (melon, onion, and tomato), as well as ornamental crops (cyclamen, gerbera, and orchids), and even on weeds or parasitic plants (broomrape and witchweed). However, individual strains display selective pathogenicity to a more or less narrow range of host plants. Strains with the same host range, generally one plant species, are grouped into a forma specialis. For example, strains responsible for Fusarium wilt of tomato belong to the forma specialis lycopersici, while those causing wilting on banana belong to the forma specialis cubense. The forma specialis concept was first created to distinguish strains of Puccinia graminis Pers. displaying similar morphological features but different host ranges. This new rank was designated as "spezialisierten formen" (Eriksson 1894). A definition was given in 1910 during the International Botanical Congress of Brussels: "In the case of parasites, especially parasitic fungi, authors who do not give specific value to forms characterized from a biological standpoint but scarcely or not at all from a morphological standpoint, should distinguish within the species special forms (forma specialis, f. sp.) characterized by their adaptation to different hosts" (Proceedings of the 3rd International Botanical Congress, 1910, Brussels Chapter II, Recommendation I bis). Since 1930, the existence of this intraspecific rank has been admitted by the International Code of Botanical Nomenclature (commonly named International Code of Nomenclature for algae, fungi and plants), but it is not codified by this international authority because accepting physiological traits represents a hurdle (Gordon 1965). Snyder and Hansen (1940) 
reported 25 "biologic forms" within $F$. oxysporum based on their host ranges. In $1965, F$. oxysporum pathogenic strains were no longer designated as forms but as formae speciales (f. sp.) (Gordon 1965). In addition, some formae speciales are subdivided into races, defined by cultivar-level specialization and, in some cases, by known resistance genes in these cultivars (Gordon and Martyn 1997). Much attention has been devoted to $F$. oxysporum over the last hundred years; it is still among the most important fungal plant pathogens based on its scientific and economic importance (Dean et al. 2012). New formae speciales and races are regularly described, but their list has not been updated for more than 35 years (Armstrong and Armstrong 1981). We searched the scientific literature and extension journals to propose this review of currently described $F$. oxysporum formae speciales and races, and of the plant species susceptible to $F$. oxysporum diseases. This review also raises issues regarding the nomenclature and the description of F. oxysporum formae speciales and races.

\section{DISEASES CAUSED BY F. OXYSPORUM}

Knowledge on root infection by $F$. oxysporum was recently reviewed (Gordon 2017). Pathogenic F. oxysporum strains are responsible for two types of symptoms, i.e., most often vascular wilting and in some cases rotting. F. oxysporum causing vascular wilting penetrates the host roots to reach the xylem vessels, which it colonizes upwards, resulting in progressive yellowing and wilting of the plant (Olivain and Alabouvette 1999). This type of symptom is the most commonly encountered one. According to the Committee on standardization of common names for plant diseases, it is associated with several disease names that are Fusarium yellows, Fusarium blight, and Fusarium wilt (The American Phytopathological Society on the standardization of common names for plant diseases, 2017; http://www.apsnet.org/publications/commonnames/Pages/default. aspx). F. oxysporum that causes rotting progresses in the roots and hypocotyl cortical tissues without reaching the vascular system (Jarvis and Shoemaker 1978). Its growth causes the formation of discolored tissues evolving into brown to black necrotic spots that end up in the rotting of the plant. Diseases with rotting symptoms are called basal rot, Fusarium stem rot, or crown and root rot. Rot diseases predominantly affect plants with storage organs such as bulbs (e.g., lily), corms (e.g., crocus), tubers (e.g., potato), and rhizomes (e.g., ginger) (Boerema and Hamers 1988, 1989; Manici and Cerato 1994; Trujillo 1963). As such organs are characterized by a shortened stem, we may hypothesize that the fungus adjusts its progression strategy in the plant tissues according to the anatomical peculiarity of the plant. The first case of rot disease caused by $F$. oxysporum was reported on lupine (Weimer 1944). To distinguish root-rot-producing strains from those producing typical vascular wilt, Weimer (1944) proposed the name F. oxysporum f. sp. radicis-lupini. Since then, the term "radicis" has differentiated rot-producing strains from wilt-producing strains. The formae speciales causing rot were taken into account in Gordon's review (Gordon 1965) but were removed from subsequent reviews (Armstrong and Armstrong 1968, 1981). However, the scientific community accepted the concept of "radicis"-type forma specialis. For example, formae speciales radicis-lycopersici and radiciscucumerinum are recognized as such for the root rot they cause on tomato and cucumber, respectively (Jarvis and Shoemaker 1978; Vakalounakis 1996). Including the term "radicis" in the name of the forma specialis allows for an immediate identification of the type of symptoms. However, some formae speciales, for example cepae, lilii, and opuntarium, cause rotting but are not referred to as formae speciales "radicis-host plant name" (Baayen et al. 1998; Brayford 1996; Polizzi and Vitale 2004). On the other hand, F. oxysporum that causes disease on vanilla was initially described as forma specialis vanillae, but it was recently renamed forma specialis radicis-vanillae regarding the disease symptoms it causes (Koyyappurath et al. 2015). Nevertheless, some plants can be attacked by two different formae speciales causing the two types of symptoms. For example, tomato is susceptible to the formae speciales lycopersici causing wilt and radicis-lycopersici causing rot. In rare cases, damping off caused by F. oxysporum has also been reported, on Pinaceae and on Allium cepa for instance (Abawi and Lorbeer 1972; Bloomberg 1971; Stewart et al. 2012). Pathogenic F. oxysporum strains are occasionally reported as part of a consortium of pathogens (Beccari et al. 2010).

\section{HOW MANY F. OXYSPORUM FORMAE SPECIALES AND RACES?}

The latest review that many scientists still refer to dates back to more than 35 years (Armstrong and Armstrong 1981). The authors reported 79 formae speciales and mentioned races in 16 formae speciales. Since then, the known host range of $F$. oxysporum has considerably increased, and many new formae speciales and races have been described. Through a comprehensive review of the literature (up to August 2018), we counted 106 formae speciales that we considered to be well documented (Table 1), 37 formae speciales that we considered as insufficiently documented (Table 2), and 58 additional host plants for which no forma specialis has been characterized so far (Table 3 ).

The host range of the formae speciales listed in Table 1 consists of plants belonging to 45 families, among which Asteraceae, Cucurbitaceae, Fabaceae, and Solanaceae are the most represented. Symptoms caused by these formae speciales correspond mainly to wilt, and for some of them to rot. Some formae speciales were described very recently, such as the formae speciales lavandulae, cichorii, crassulae, and mori (Ortu et al. 2013, 2018; Pastrana et al. 2017; Poli et al. 2012). The initially restricted host range was expanded from one to several plant species for many formae speciales (see next section). Races mostly based on cultivar-level specialization were identified in 25 of the 106 formae speciales listed in Table 1. However, the notion of race is not always used in the same way by authors, and this makes it difficult to characterize pathogenic variants within $F$. oxysporum. For example, pathogens of different Brassicaceae species have been described as different formae speciales (conglutinans, matthioli, and raphani), or as races of the forma specialis conglutinans (Table 1). Therefore, special focus is brought to the concept of race in a following section.

Table 2 groups 37 formae speciales that we consider as insufficiently documented. These formae speciales mainly correspond to (i) pathogens isolated from diseased plants and assigned to a forma specialis without having been inoculated on the plant species of origin to confirm their pathogenicity, (ii) pathogens whose host specificity was not analyzed, and (iii) pathogens reported in Gordon's (1965) or Armstrong and Armstrong's (1968, 1981) reviews for which we did not have access to a publication describing the forma specialis. Moreover, some pathogens initially identified as $F$. oxysporum may belong to other closely related species such as some strains causing disease on pine and which actually belong to the recently described species $F$. commune (Gordon et al. 2015). We also included in Table 2 the formae speciales cucurbitacearum and iridacearum that have been proposed to group all formae speciales pathogenic on plants from the families Cucurbitaceae and Iridaceae, respectively (Gerlagh and Blok 1988; Palmero et al. 2014; Roebroeck 2000).

Furthermore, the host range of $F$. oxysporum is regularly extended with the emergence of new diseases. We recorded 58 plant species or genera in the literature described as susceptible to F. oxysporum but whose forma specialis has not been characterized yet (Table 3 ). These 58 host plants belong to 38 different families, among which 17 are not identified in Tables 1 and 2. A total of 45 of these 58 new host plants were reported very recently, i.e., in the 2000s. The diseases caused by these "new" pathogens are mostly wilt, rot to a lesser extent, and more rarely a few other symptoms (Table 3 ). It is likely that the number of $F$. oxysporum formae 
speciales and races will keep increasing in the future. F. oxysporum host plants have been identified on all continents except the Antarctic, and its overall host range listed in the three tables presented in this review includes 73 different plant families that already represent a large host spectrum. In addition, most of these known hosts are plants of agronomic and ornamental interest, which for practical and economic reasons have so far attracted more attention than wild plants. The currrent need to control weeds by alternatives to chemical methods reveals that these plants are also infested by pathogens, including $F$. oxysporum strains that are potential candidates for weed biological control (Boari and Vurro 2004; Elzein et al. 2008). Moreover, the distribution of F. oxysporum is ubiquitous, so that there is a good chance that new $F$. oxysporum-host plant interactions, and thus new formae speciales will soon be revealed in addition to those already proposed (Table 3). Such a wide geographical distribution and wide host spectrum confirms the adaptability of $F$. oxysporum to the diverse biotic and abiotic environmental conditions encountered worldwide (Steinberg et al. 2016).

\section{AN EVOLVING FORMA SPECIALIS CONCEPT?}

F. oxysporum formae speciales are mainly described as highly specific. Their host range was initially supposed to be restricted to one plant species, but it was found to be broader for many formae speciales over time. Only 53 of the 106 formae speciales listed in Table 1 remain associated with a unique plant species to date. This number can even be less, based as few potential hosts have been tested even for well-studied formae speciales. Thus, the actual host range for any given forma specialis could well be much wider than currently recognized. Several of them were found to be pathogenic to (i) several species within a genus, e.g., forma specialis narcissi, or (ii) several genera within a plant family, e.g., forma specialis gladioli that is pathogenic to different Iridaceae plants, or finally (iii) plants belonging to different families, e.g., forma specialis vasinfectum (Table 1). Some plant species may be more permissive than others to various fungal attacks. Thus, Maltese cross appears to be a secondary host for three different formae speciales (conglutinans, dianthi, and spinaciae) (Table 1). The difficulty in defining the host specificity of $F$. oxysporum pathogenic strains is confounding for several formae speciales. That is why cross-pathogenicity of formae speciales cucumerinum, niveum, lagenariae, and luffae on their respective host plants led Gerlagh and Blok (1988) to propose to group all formae speciales pathogenic on cucurbitaceous crops into the new forma specialis cucurbitacearum. The situation is also confused for $F$. oxysporum that attacks iridaceous crops. Formae speciales gladioli, croci, and saffrani have all been described as pathogenic on Crocus spp., and the host range of the forma specialis gladioli includes several Iridaceae genera. Roebroeck (2000) proposed to assign all the strains pathogenic to iridaceous crops to a new forma specialis called iridacearum.

Half of the formae speciales described so far (Table 1) are, to our current knowledge, each pathogenic to one host plant only, while the other half includes strains whose interaction specificity is much wider and sometimes leads to cross-pathogenicity. It is always possible to think that the conditions under which pathogenicity tests are carried out favor the infection of plants by strains that may not necessarily be pathogenic in natural situations. However, it is difficult to imagine that half of the tests performed so far were "false positives" caused by too high inoculum doses. Nevertheless, most of the extended host ranges reported in Table 1 were obtained under artificial inoculation conditions. This was not the case for the forma specialis radiciscucumerinum that attacked cucumber but also melon under natural conditions (Vakalounakis et al. 2005).

It is now well documented that a strain of $F$. oxysporum pathogenic to a given host plant can be genetically closer to a strain pathogenic to another plant species, or even closer to a nonpathogenic strain than to a strain pathogenic to the same host plant (Baayen et al. 2000; Fourie et al. 2009; Inami et al. 2014; O'Donnell et al. 2009). The existence of many transposons is likely to generate mutations leading to the expression of different effectors (Chalvet et al. 2003; Daboussi and Capy 2003). Horizontal gene transfer is another mechanism that can explain genetic diversity among strains that are pathogenic to a given plant species (Ma 2014). Horizontal gene transfer may also explain cross-pathogenicity phenomena. Horizontal gene transfer between pathogenic and nonpathogenic $F$. oxysporum strains has indeed been demonstrated under controlled conditions, but competition among F. oxysporum populations at the plant root surface in the host plant rhizosphere provides favorable conditions for such horizontal gene transfers.

\section{SPECIAL FOCUS ON THE CONCEPT OF RACE}

The concept of physiological race was mentioned for Puccinia graminis in 1913 (Stakman 1913). It was defined as "a biotype or group of biotypes, within a species or lower taxon, which can be distinguished with reasonable facility and certainty from other biotypes or groups of biotypes by physiologic characters, including pathogenicity" (Stakman et al. 1962). Like the forma specialis, the race is not a formal taxonomic rank and is not codified by the International Code of Nomenclature for algae, fungi and plants. Therefore, there is no standardized procedure for naming races. They are generally numbered in chronological order of discovery. In some cases, they are defined according to the avirulence genes born by the strains included in the races, or according to the host plant resistance genes they overcome, as in the case of $F$. oxysporum f. sp. lycopersici (Alexander and Tucker 1945; Bohn and Tucker 1939). In the absence of a known genefor-gene relationship, races are often defined according to differential pathogenicity on different cultivars (Habgood 1970). The use of variable criteria to describe new races has led to confusion in several formae speciales. For example, up to 11 races were initially described in the forma specialis pisi before a revision cut that number down to four (Table 1). In some formae speciales, races are described according to climatic predisposition (e.g., forma specialis cubense races subtropical and tropical 4), or according to differences in plant symptoms (e.g., forma specialis melonis races $1-2 \mathrm{~W}$ and $1-2 \mathrm{Y}$ causing wilting and yellowing symptoms, respectively) (Ploetz 2006; Risser et al. 1976). Such subgroupings are convenient as, in some cases, different patterns of symptom development are indicative of genetically distinct strains. F. oxysporum races reflect variations in virulence within the forma specialis, revealed by differential interactions with different host genotypes sometimes linked to known resistance genes. Thus, the definition of a new race intrinsically requires evaluating the pathogenicity of the strains on several host plant genotypes. The distinction between a forma specialis and a race may be narrow in some cases. For example, forma specialis conglutinans was initially described as responsible for wilting on Brassicaceae (Kendrick 1930; Pound and Fowler 1951). Later, forma specialis conglutinans strains responsible for wilting on stock and radish were reclassified as forma specialis matthioli and forma specialis raphani, respectively (Baker 1948; Kendrick and Snyder 1942), and later again as races 2 and 3 of forma specialis conglutinans (Armstrong and Armstrong 1952, 1981). Later on, Bosland and Williams (1987) restored the formae speciales conglutinans, matthioli, and raphani on the basis of pathogenic and genetic diversity. To avoid such classification issues, races should be ideally based on a gene-for-gene relationship between a pathogenic strain and its host plant; if not applicable, they should be at least defined by a clear-cut cultivar-level specialization. 
TABLE 1

Fusarium oxysporum formae speciales and races and their corresponding host plants

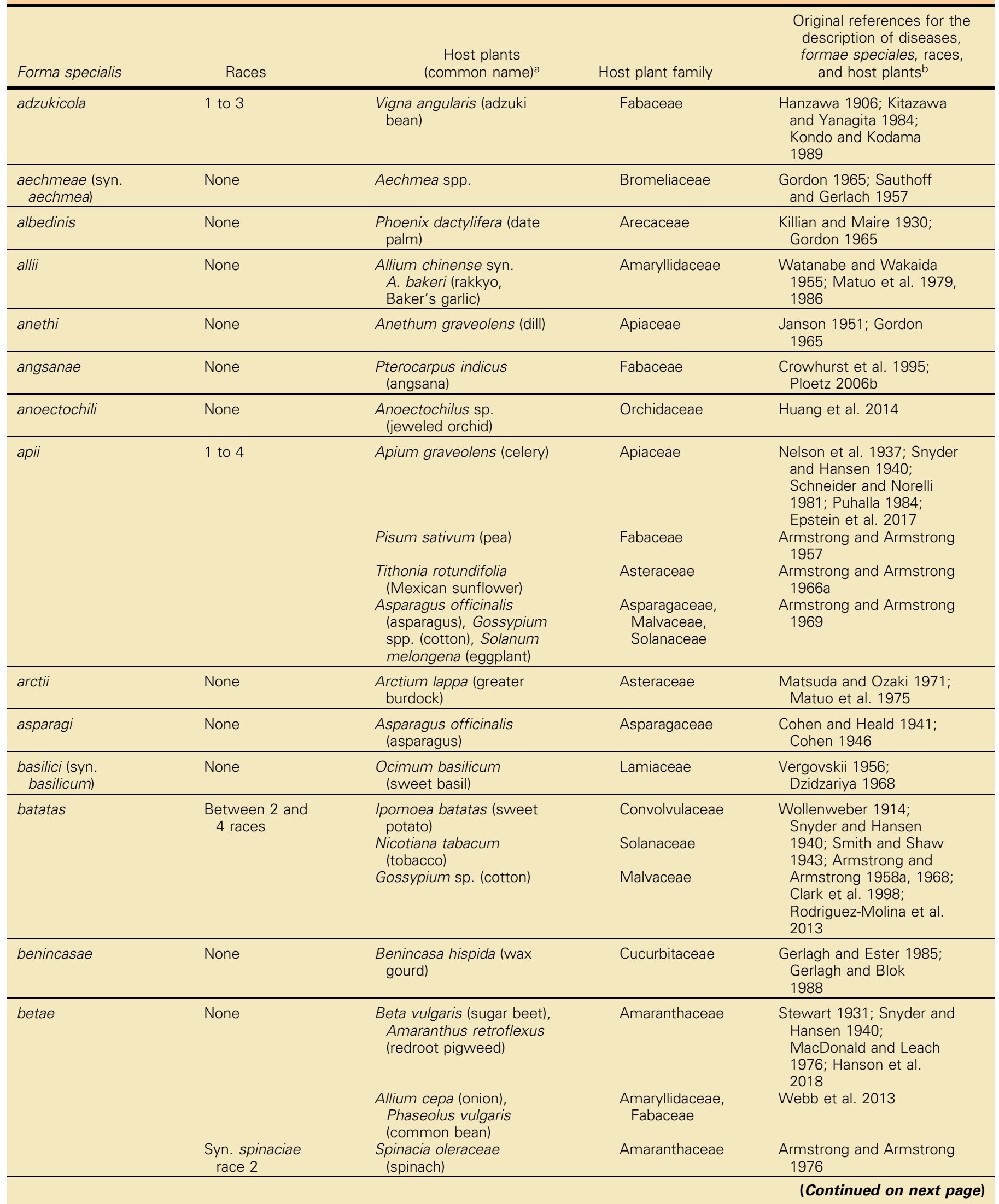

a According to the Integrated Taxonomic Information System (ITIS).

b Supplementary File S1 provides a complete list of the references listed in this table. 
TABLE 1

(Continued from previous page)

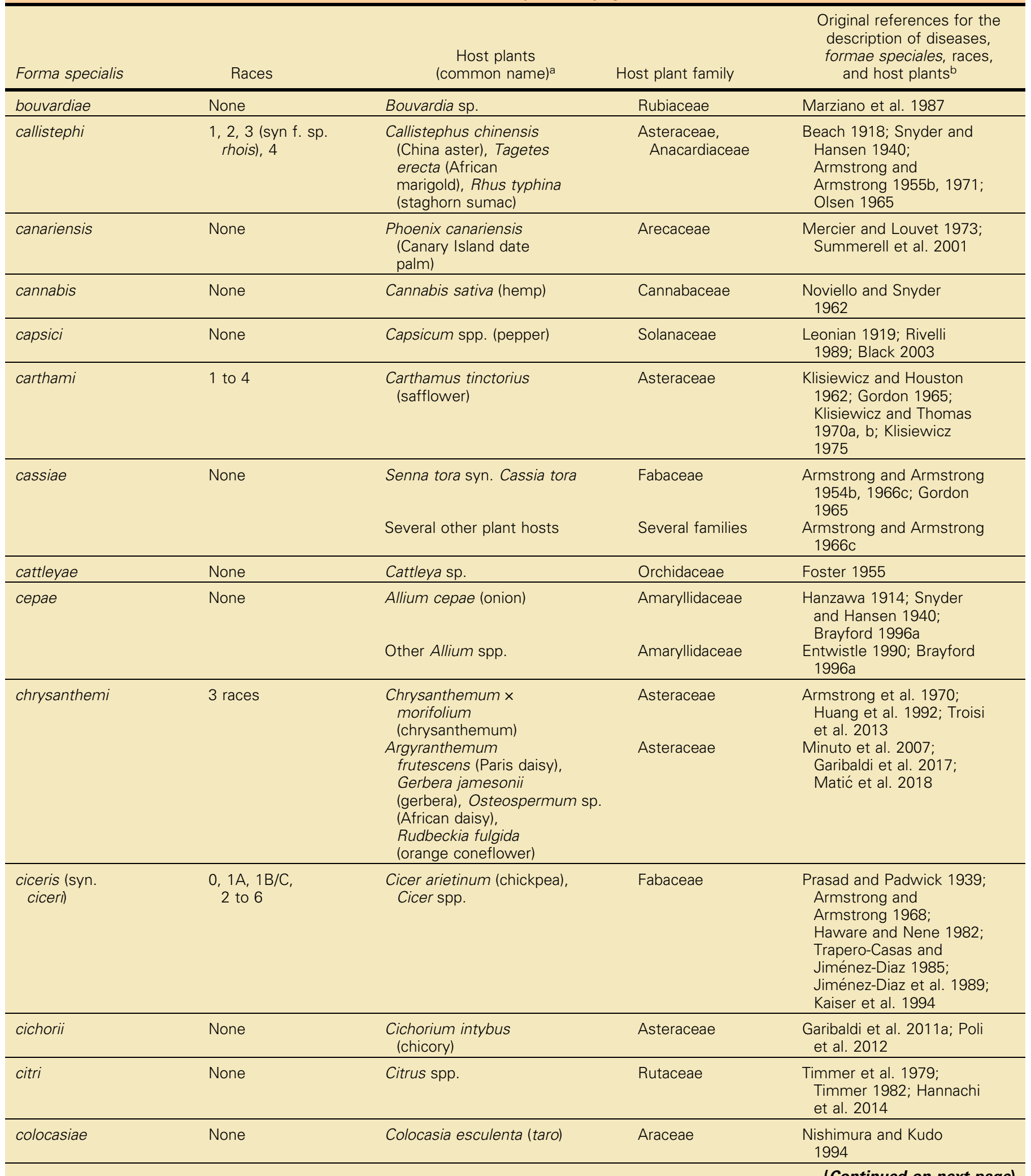

(Continued on next page) 
TABLE 1

(Continued from previous page)

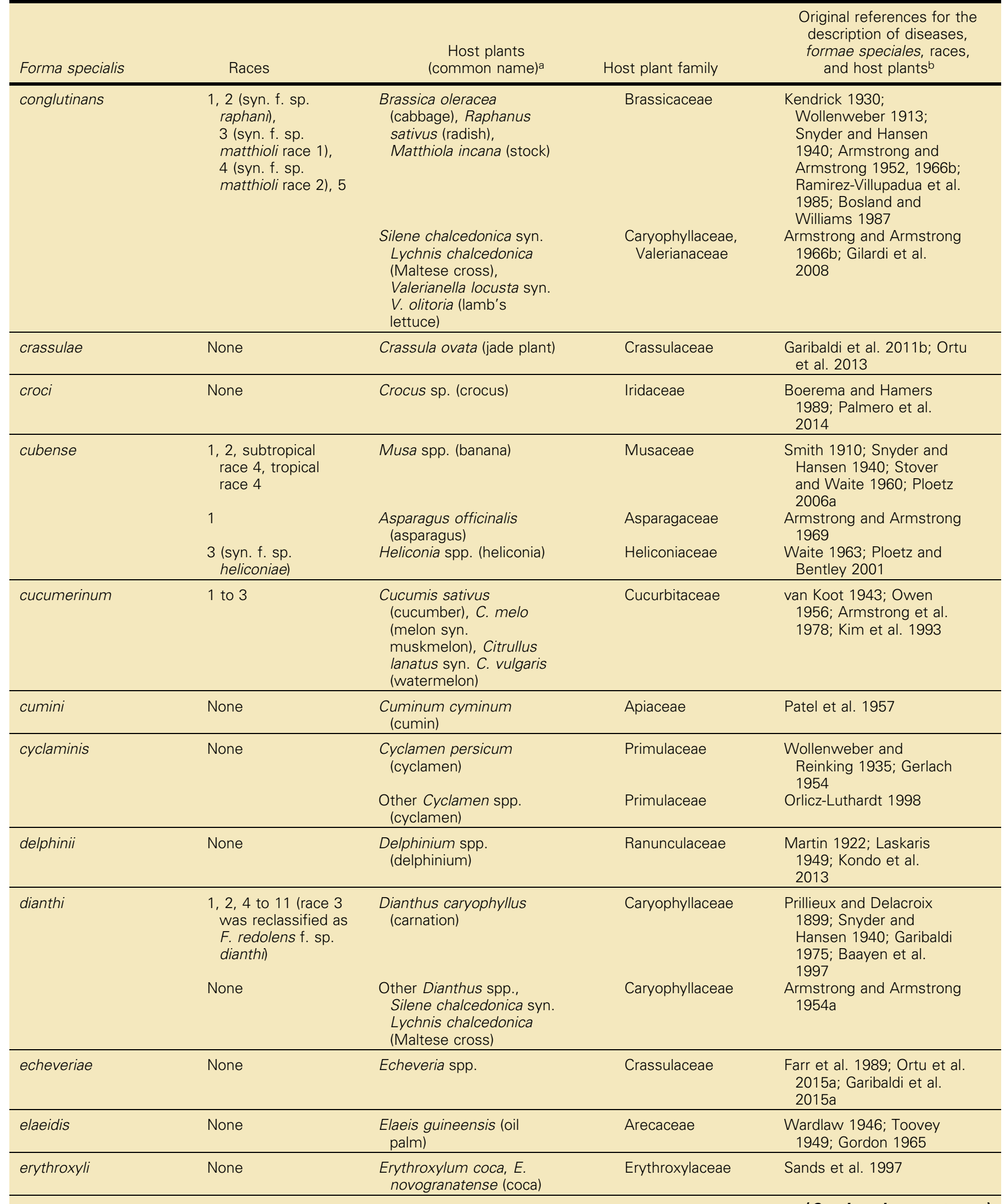

(Continued on next page) 
TABLE 1

(Continued from previous page)

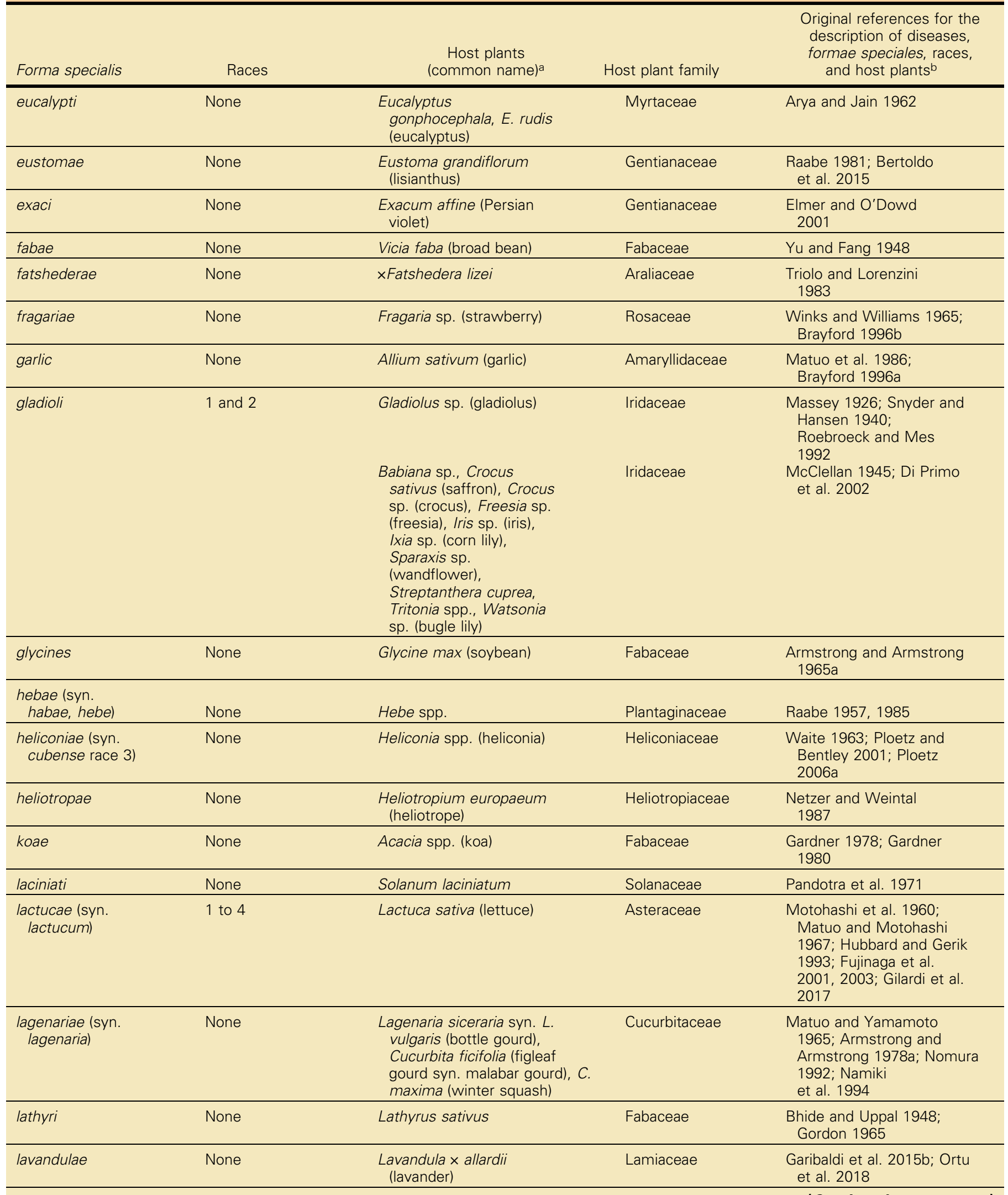


TABLE 1

(Continued from previous page)

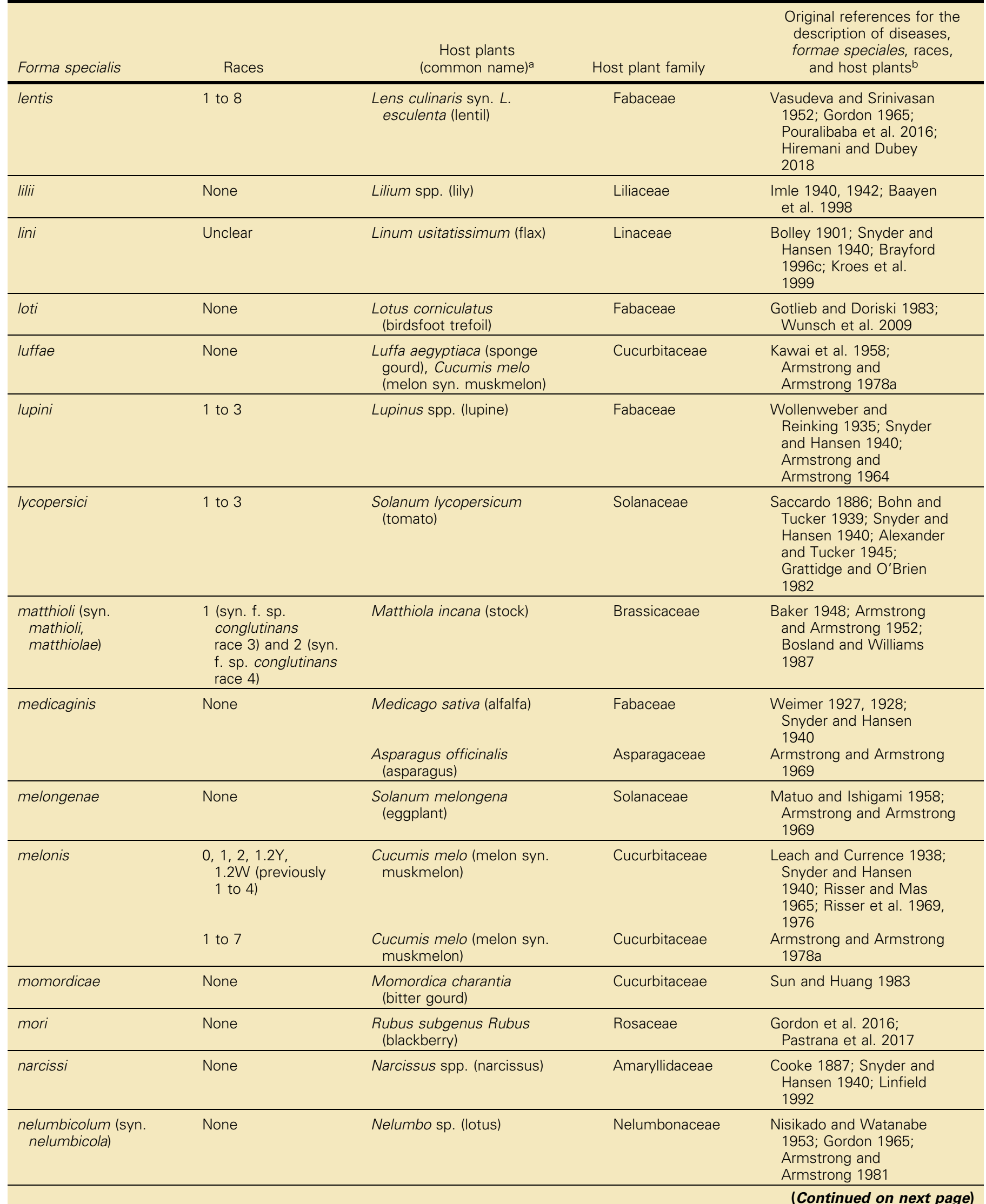


TABLE 1

(Continued from previous page)



(Continued on next page) 


\section{TABLE 1}

(Continued from previous page)

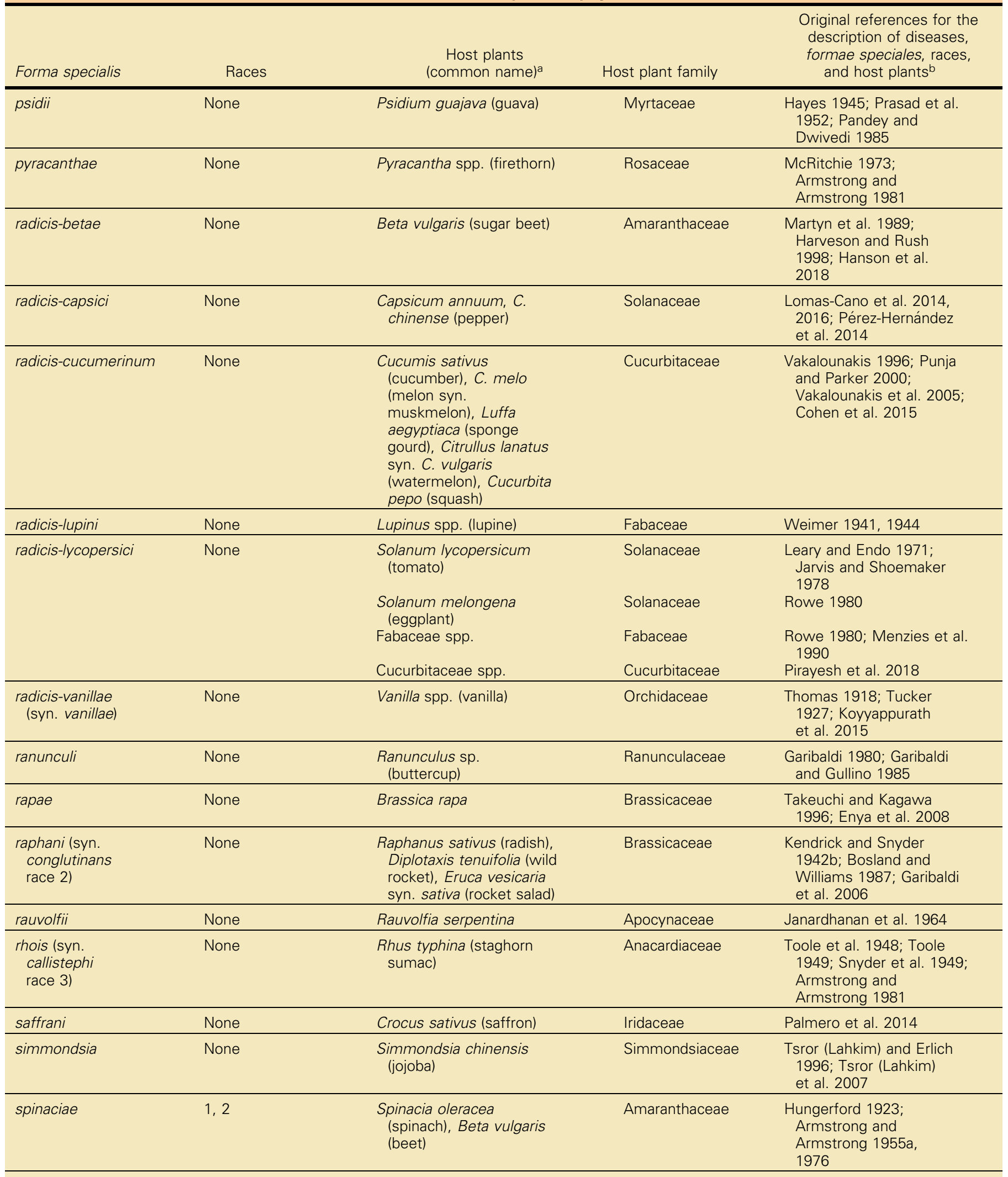

(Continued on next page) 
Races have been described in 25 of the 106 formae speciales described to date. These are formae speciales corresponding to plants of agronomic or ornamental interest. Although causality has not been demonstrated, it is difficult not to incriminate the role of humans in the current distribution and the emergence of new races within formae speciales. When interaction frequency between the host plant and the pathogenic $F$. oxysporum is low, as is the case with a few cultivated plants or plants not submitted to intensive cultivation, we may reasonably think that the first races that are described result from coevolution between pathogenic $F$. oxysporum strains within a forma specialis and the host plant, therefore gene-for-gene relationships are expected. In view of the genetic selection done by breeders, it is more difficult to know if the newly cultivated genotypes act as accelerators of the evolution of phytopathogenic fungi or only reveal preexisting bypass genes that nothing could highlight otherwise. It is therefore clear that molecular markers are needed to unambiguously identify the races within formae speciales but also to understand the mechanisms of their emergence, even if this results in revising the initially defined genefor-gene contours of the race concept.

TABLE 1

(Continued from previous page)

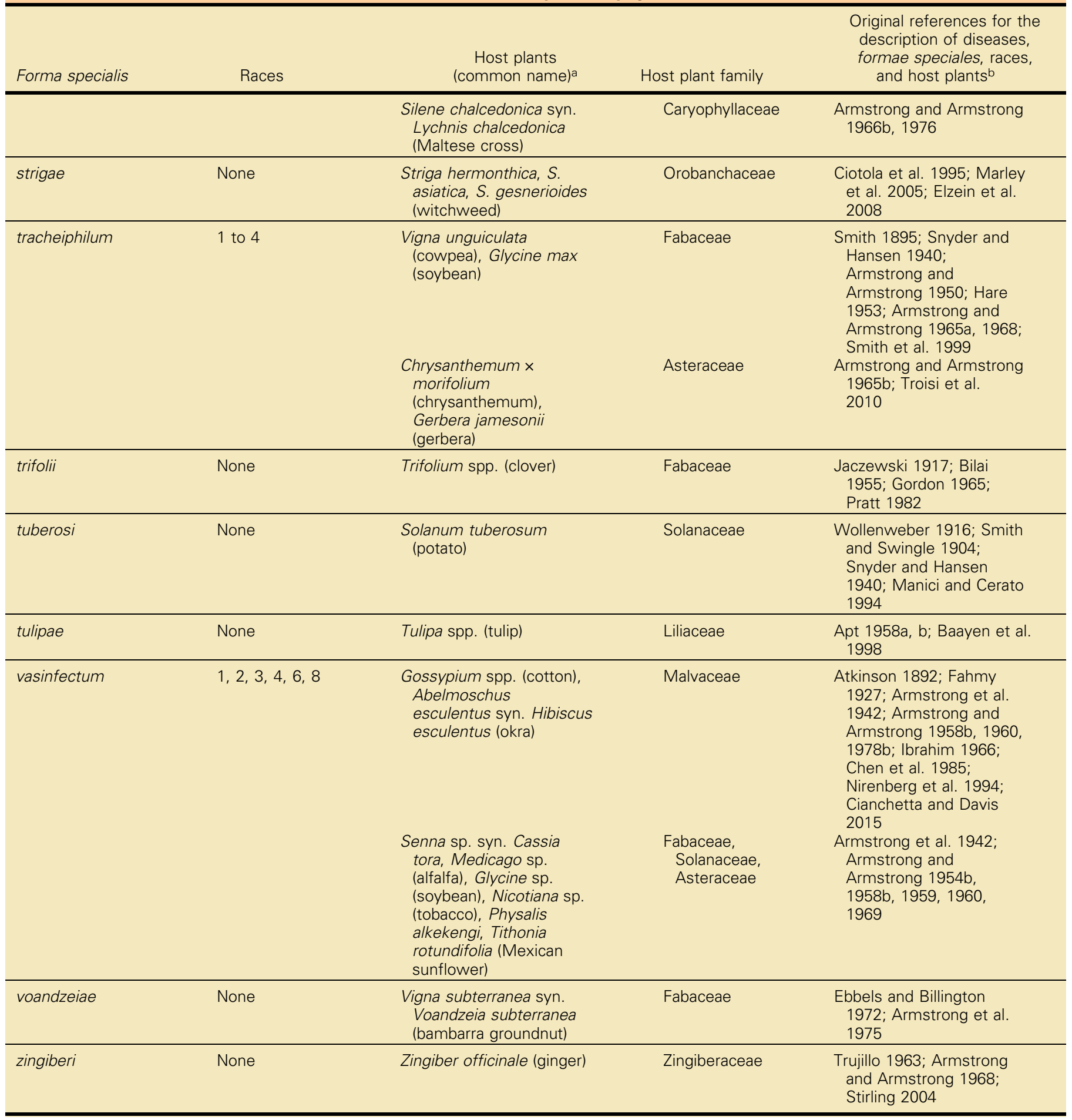




\section{HOW TO DESCRIBE A NEW FORMA SPECIALIS OR RACE?}

The forma specialis is not a taxonomic rank, therefore the nomenclature of formae speciales is not codified by the International Code of Nomenclature for algae, fungi and plants (Art. 4 Note 4). In other words, the definition of a new forma specialis does not follow the rules of nomenclature established by the International Code of Nomenclature for algae, fungi and plants. Any author describing a new forma specialis is free to choose its name. As a result, many formae speciales were named according to the host plant Latin name, either the genus name or the species name, or according to the host plant common name (Table 1). The lack of any standardized nomenclature causes confusion in the definition of

TABLE 2

Insufficiently documented Fusarium oxysporum formae speciales

\begin{tabular}{|c|c|c|c|c|}
\hline Forma specialis & $\begin{array}{c}\text { Host plants } \\
\text { (common name) }^{a}\end{array}$ & Host plant family & References ${ }^{b}$ & Comments \\
\hline adzuki & Glycine max & Fabaceae & John et al. 2010 & $\begin{array}{l}\text { Insufficiently documented } \\
\text { forma specialis }\end{array}$ \\
\hline aleuritidis & Vernicia fordii (tungoil tree) & Euphorbiaceae & Suelong 1981 & $\begin{array}{l}\text { Insufficiently documented } \\
\text { forma specialis }\end{array}$ \\
\hline amaranthi & $\begin{array}{l}\text { Amaranthus hybridus } \\
\text { (amaranth) }\end{array}$ & Amaranthaceae & $\begin{array}{l}\text { Chen and Swart 2001; Leslie } \\
\text { and Summerell } 2006\end{array}$ & $\begin{array}{l}\text { Insufficiently documented } \\
\text { forma specialis }\end{array}$ \\
\hline blasticola & Conifers & Several families & Bilai 1955; Gordon 1965 & $\begin{array}{l}\text { Synonym of forma specialis } \\
\text { pini according to Gordon } \\
1965\end{array}$ \\
\hline coffeae & Coffea arabica (coffee) & Rubiaceae & Garcia 1945 & $\begin{array}{l}\text { Insufficiently documented } \\
\text { forma specialis }\end{array}$ \\
\hline cucurbitacearum & Cucurbitaceae spp. & Cucurbitaceae & Gerlagh and Blok 1988 & $\begin{array}{l}\text { Gerlagh and Blok (1988) } \\
\text { proposed to group } \\
\text { together all the formae } \\
\text { speciales pathogenic to } \\
\text { plants from the family } \\
\text { Cucurbitaceae }\end{array}$ \\
\hline dahliae & Dahlia sp. (dahlia) & Asteraceae & $\begin{array}{l}\text { Solovjova and Madumarov } \\
\text { 1969; Armstrong and } \\
\text { Armstrong } 1981 \\
\end{array}$ & $\begin{array}{l}\text { Insufficiently documented } \\
\text { forma specialis }\end{array}$ \\
\hline dioscoreae & Dioscorea rotundata (yam) & Dioscoreaceae & Wellman 1972 & $\begin{array}{l}\text { Insufficiently documented } \\
\text { forma specialis }\end{array}$ \\
\hline elaeagni & Elaeagnus sp. & Elaeagnaceae & $\begin{array}{l}\text { Armstrong and Armstrong } \\
1968\end{array}$ & $\begin{array}{l}\text { Insufficiently documented } \\
\text { forma specialis }\end{array}$ \\
\hline gerberae & $\begin{array}{l}\text { Gerbera jamasonii, hybrids } \\
\text { (gerbera) }\end{array}$ & Asteraceae & von Arx 1952; Gordon 1965 & $\begin{array}{l}\text { Insufficiently documented } \\
\text { forma specialis }\end{array}$ \\
\hline herbemontis & Vitis spp. (grape) & Vitaceae & Tochetto 1954; Gordon 1965 & $\begin{array}{l}\text { Insufficiently documented } \\
\text { forma specialis }\end{array}$ \\
\hline hyacinthi & Hyacinthus sp. (hyacinth) & Asparagaceae & $\begin{array}{l}\text { Muller 1978; Baayen et al. } \\
2001\end{array}$ & $\begin{array}{l}\text { Possible confusion with } \\
\text { F. hostae }\end{array}$ \\
\hline iridacearum & Iridaceae spp. & Iridaceae & $\begin{array}{l}\text { Roebroeck 2000; Palmero } \\
\text { et al. } 2014\end{array}$ & $\begin{array}{l}\text { Roebroeck (2000) proposed } \\
\text { to group together all the } \\
\text { formae speciales } \\
\text { pathogenic to plants from } \\
\text { the family Iridaceae }\end{array}$ \\
\hline
\end{tabular}

\footnotetext{
a According to the Integrated Taxonomic Information System (ITIS).

b Supplementary File S2 provides a complete list of the references listed in this table.
} 
formae speciales. Thus, some formae speciales have multiple names, e.g., the forma specialis matthioli also named mathioli or matthiolae. Any description of a new forma specialis or race should only be published after a meticulous search in the literature to avoid any duplicate entry. Moreover, pathogenicity should be evaluated in such conditions that the full pathogenic potentiality of the fungal isolate is expressed, i.e., controlled conditions, nonexcessive inoculum dose and clearly identified susceptible cultivar. We suggest that proposing a new forma specialis or race should require the following at a minimum:

- Morphological and molecular identifications of the new isolate at the species level.

TABLE 2

(Continued from previous page)

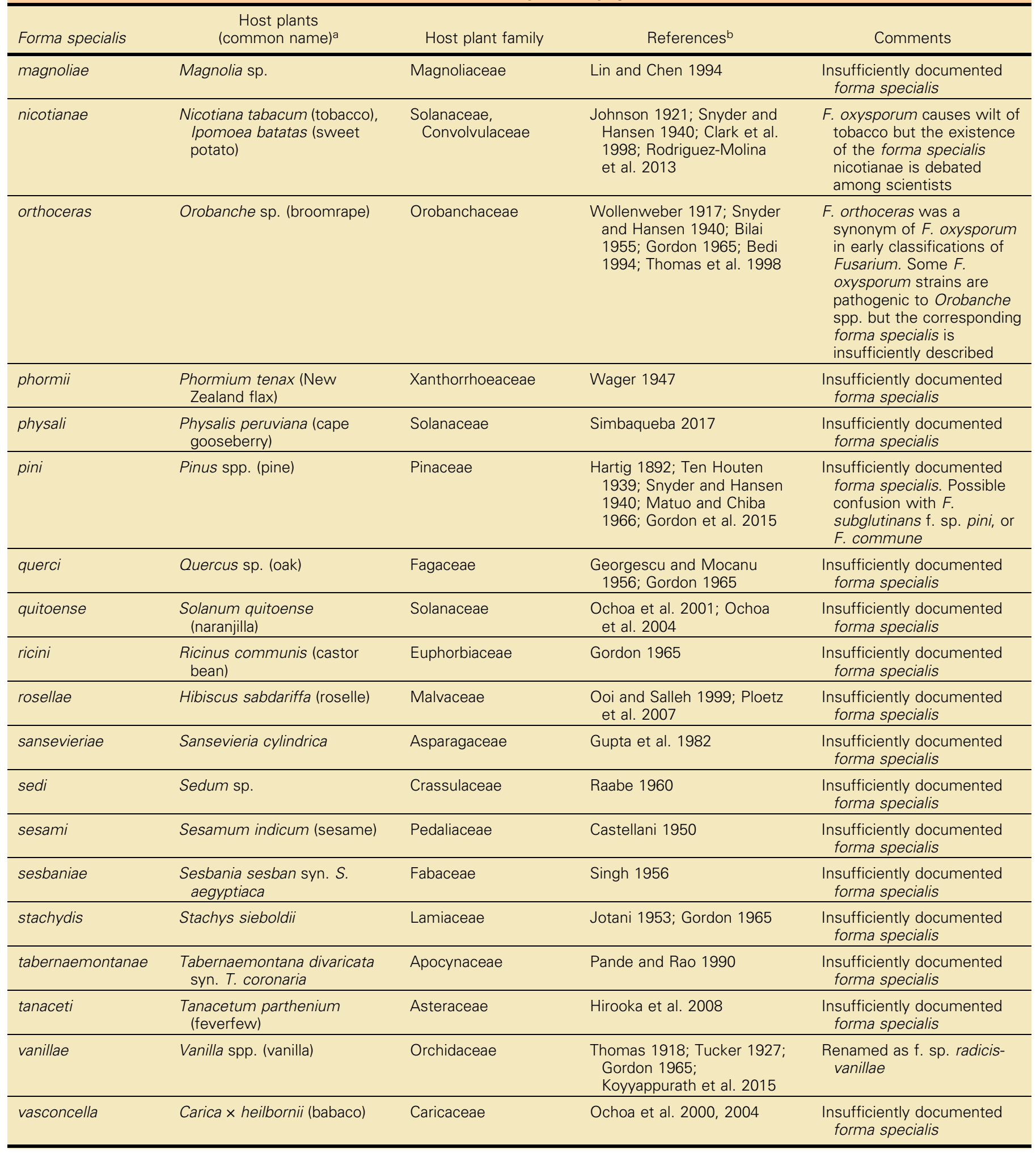


- A full description of the protocol used for validating Koch's postulates, including the protocol and results of the pathogenicity test(s) together with the observed symptoms.

- Evaluation of the specificity of the interaction between the new pathogenic strain and the host plant, and characterization of the host spectrum of the strain; appropriate crops to include would be those in the same plant family and/or grown in rotation with the known susceptible host.

- The name of the new forma specialis according to the host plant Latin name when possible.

- The race number according to the chronological order of discovery, and the identified virulence gene, if any.
- The accepted Latin binomial name of the host plant and the identified resistance gene, if any.

- The names of one or more cultivars that have been demonstrated to be susceptible, along with differential cultivars where races have been described. Ideally, these are publicly available cultivars.

- The deposition of representative isolates in an international collection of microorganisms.

- The preservation of the host plant germplasms in an international collection, especially when a new race is described.

- Publication in a peer-reviewed journal including all the biological details and providing the accession numbers in the text.

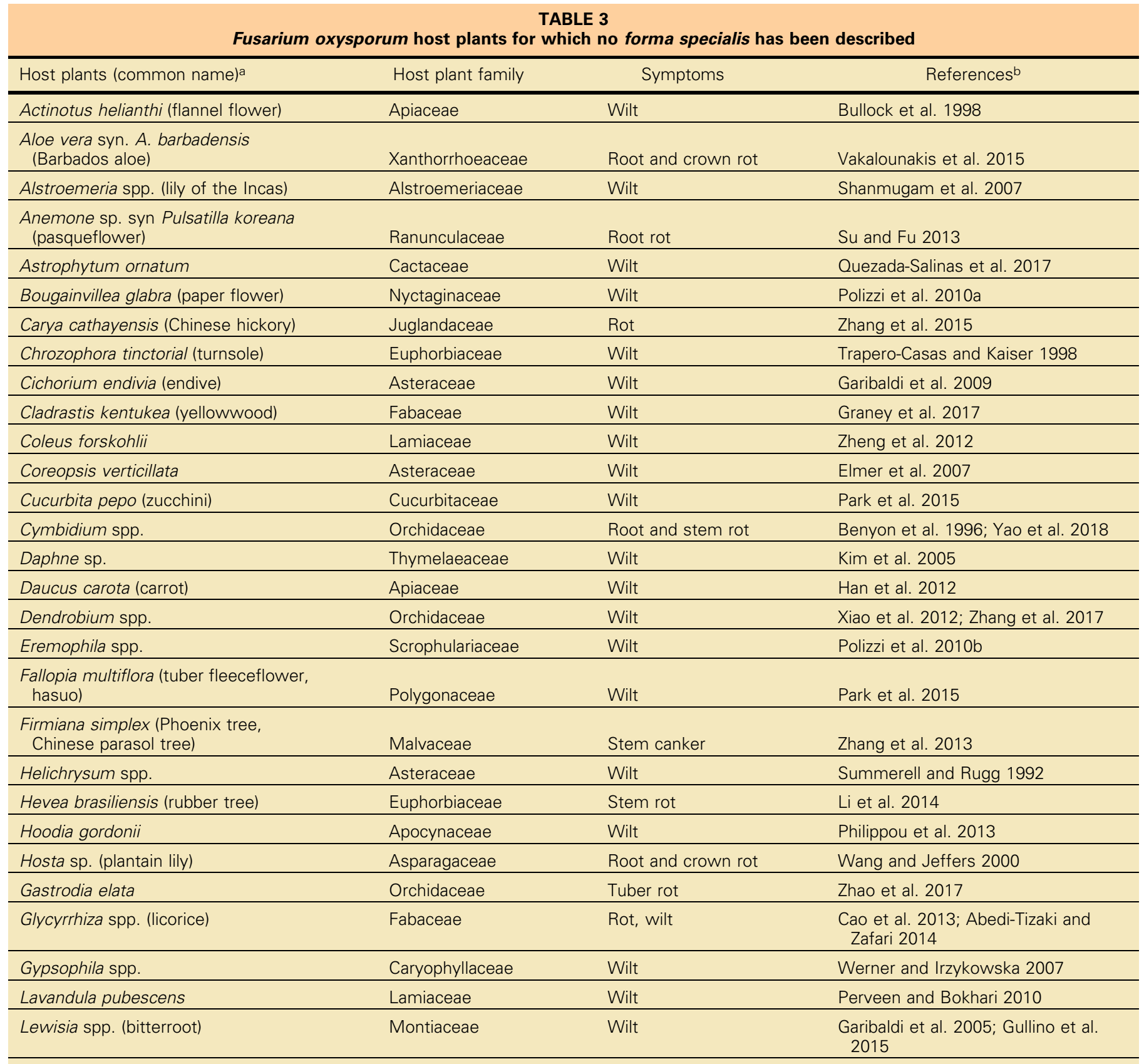

(Continued on next page)

\footnotetext{
${ }^{a}$ According to the Integrated Taxonomic Information System (ITIS).

${ }^{b}$ Supplementary File S3 provides a complete list of the references listed in this table.
} 


\section{TOWARD MOLECULAR TOOLS TO IDENTIFY F. OXYSPORUM FORMAE SPECIALES AND RACES}

The internal transcribed spacer (ITS) has been proposed as the barcode for fungal species identification (Seifert 2009). However, this DNA marker cannot identify all Fusarium species unequivocally (O'Donnell and Cigelnik 1997). The translation elongation factor 1- $\alpha(T E F 1)$ and the DNA-directed RNA polymerase II largest subunit $(R P B 1)$ and second largest subunit $(R P B 2)$ are Fusarium phylogenetically informative loci and allow for species identification (O'Donnell et al. 2013, 2015). The TEF1 locus is also informative at the intraspecific level and can be combined with others such as the ribosomal intergenic spacer to reveal the complex genetic diversity within F. oxysporum (Canizares et al. 2015; EdelHermann et al. 2012, 2015; Lecomte et al. 2016; O'Donnell et al. 2009; Ortu et al. 2018). Sequence resources are available in the FUSARIUM-ID database (http://isolate.fusariumdb.org/guide.php; Geiser et al. 2004; Park et al. 2011) and the Fusarium MLST database (http://www.westerdijkinstitute.nl/fusarium/; O’Donnell et al. 2010). The literature about $F$. oxysporum genetic diversity is very abundant. Studies are based on the use of various molecular tools that have evolved over time, as well as on the use of vegetative compatibility groups (VCGs) that group together genetically similar strains (Puhalla 1985). The number of VCGs in a given forma specialis is generally between 1 and 10, but can be up to 24 as in forma specialis cubense (Aguayo et al. 2017; Katan 1999; Kistler et al. 1998).

F. oxysporum diversity studies aim at identifying specific forma specialis markers to design diagnostic tools (Lievens et al. 2008). Many formae speciales are known to be polyphyletic, making it difficult to identify specific molecular markers (Baayen et al. 2000; Epstein et al. 2017; Fourie et al. 2009; Hill et al. 2011; Koyyappurath et al. 2015; O'Donnell et al. 1998, 2009). Additionally, soilborne and endophytic nonpathogenic $F$. oxysporum isolates can be highly variable genetically and closely related to pathogenic ones (Baayen et al. 2000; Edel et al. 2001; Fourie et al. 2009; Imazaki and Kadota 2015; Inami et al. 2014). One approach used to identify molecular markers of $F$. oxysporum formae speciales or races relies on insertion

TABLE 3

(Continued from previous page)

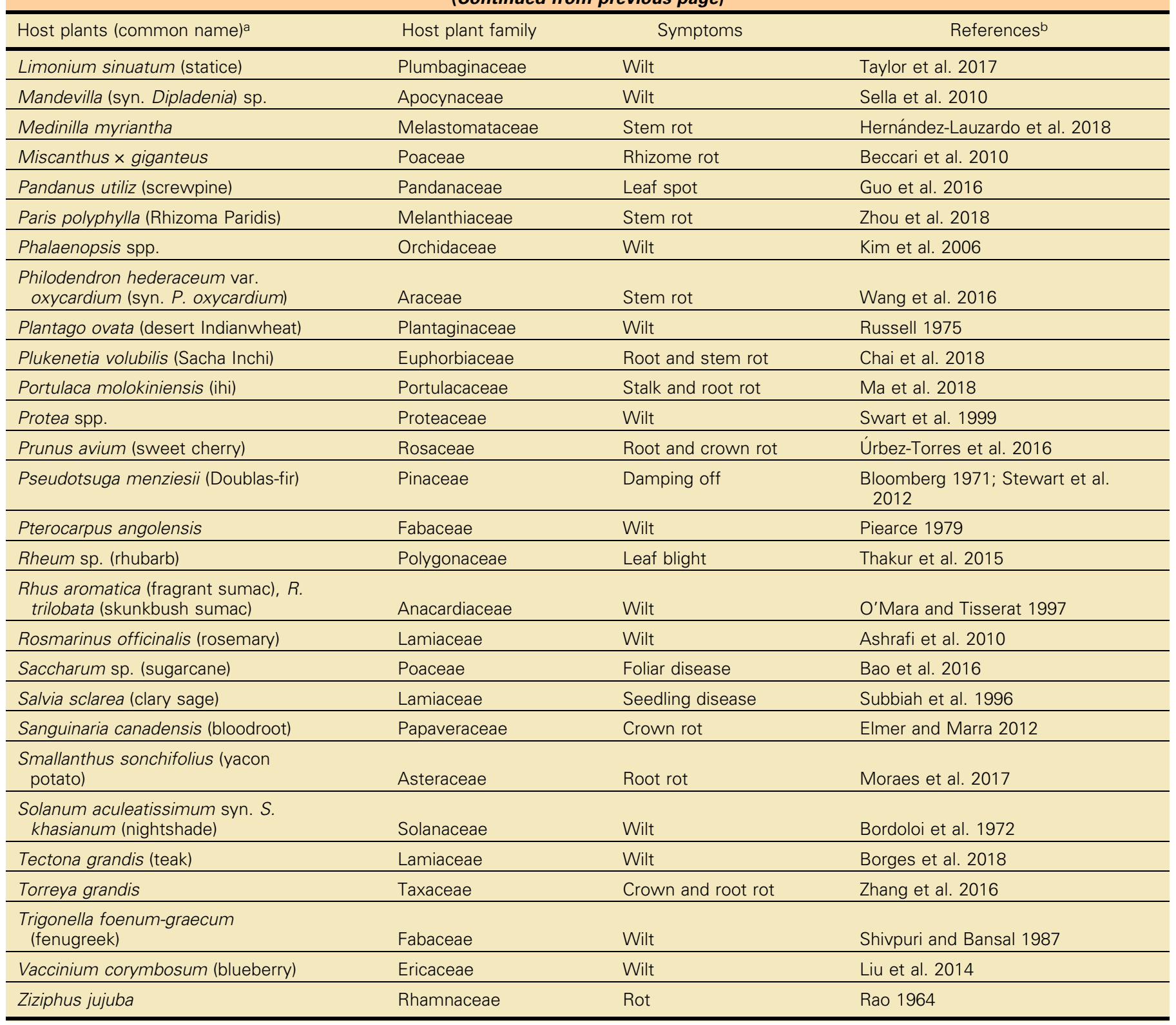


sites of transposable elements; it provided specific detection tools for formae speciales albedinis and lactucae, among others (Fernandez et al. 1998; Pasquali et al. 2007). In other cases, random amplified polymorphic DNA allowed researchers to identify sequencecharacterized amplified region (SCAR) markers. Following this strategy, detection tools were developed for formae speciales basilici, cyclaminis, phaseoli, eustomae, cucumerinum, and radicis-cucumerinum (Alves-Santos et al. 2002; Chiocchetti et al. 2001; Lecomte 2016; Li et al. 2010; Lievens et al. 2007). A few SCAR primers specifically detected races, e.g., in formae speciales ciceri and melonis (Jiménez-Gasco and Jiménez-Díaz 2003; Luongo et al. 2012).

Molecular identification of $F$. oxysporum formae speciales would ideally target pathogenicity-related genes. Although knowledge on these genetic determinants was scarce until recently, it has considerably improved in the last decade. One of the first such tools was developed for the forma specialis lycopersici, based on a host-specific virulence gene (Rep et al. 2004; Lievens et al. 2009). The gene encodes a small protein secreted in the xylem (SIX) which confers virulence to the fungus. Fourteen SIX genes are currently known, and a few homologs were found in other formae speciales such as cepae, cubense, and conglutinans (Fraser-Smith et al. 2014; Li et al. 2016; Taylor et al. 2016; van Dam et al. 2016). PCR primers were designed from SIX sequences to discriminate the formae speciales cubense and lycopersici from other formae speciales (Fraser-Smith et al. 2014; Lievens et al. 2009). Molecular markers based on other virulence factors were also designed for forma specialis phaseoli and for race 4 of forma specialis cubense (Aguayo et al. 2017; Sousa et al. 2015). Apart from effector genes, other genes involved in $F$. oxysporum pathogenicity have been described as genes encoding cell wall-degrading enzymes or transcriptional regulators (Jonkers et al. 2009; Michielse et al. 2009a, 2009b). However, comparative genomics is the next step to identify host specificity in F. oxysporum. van Dam et al. (2016) performed whole genome sequencing of $45 \mathrm{~F}$. oxysporum strains and managed to differentiate formae speciales cucumerinum, niveum, melonis, radicis-cucumerinum, and lycopersici on the basis of their effector pattern. Two years later, van Dam et al. (2018) designed PCR primers to discriminate the seven formae speciales that affect Cucurbitaceae based on candidate effectors extracted from 82 genome assemblies. There is no doubt that the expanding access to whole-genome sequences will continuously improve F. oxysporum host range identification.

\section{SUMMARY AND FUTURE PROSPECTS}

Many authors admit that the number of $F$. oxysporum formae speciales and races described in the review of Armstrong and Armstrong (1981) is out of date and suggest various and unfounded estimates of this number in the introduction of many papers dealing with $F$. oxysporum. More than the need to correct these estimates, the concomitant evolution of knowledge about the ecology of this complex species, the economic importance of its pathogenic/ nonpathogenic activity, the development of tools-especially molecular-based genomic tools-to study it, and the redefinition of the concepts related to its characterization motivated our study and led us to revisit the literature on F. oxysporum in depth. Our analysis reveals that to date, 106 formae speciales have indeed been clearly described within $F$. oxysporum, and among these, 25 harbor from 2 to 24 races. However, these numbers are not definitive and are likely to change very soon for several reasons. The first reason is that 37 putative formae speciales have been described, but their characterization is insufficient to assert that they are indeed formae speciales, and 58 additional host plants have been reported. The second reason is related to the fact that studies have mainly focused on the pathogenic activity of $F$. oxysporum on plants of economic interest, but many uncultivated (wild) plants can also be infected by new formae speciales that remain to be described. Considering the proven numbers of formae speciales and formae speciales hosting races provided by Armstrong and Armstrong (1981) (79 and 16, respectively) and those given by our study (106 and 25, respectively), the relative proportion of formae speciales hosting races has increased slightly. This increase might reflect a somewhat worrisome trend, as more and more new races are described within formae speciales in connection with the re-emergence of diseases on market gardening and ornamental crops but also on large scale crops, such as banana Fusarium wilt caused by race TR 4 of $F$. oxysporum f. sp. cubense (Gilardi et al. 2017; Ploetz 2015; Zhou et al. 2010).

Greater diversity in $F$. oxysporum and within formae speciales may be revealed over time by using new plant genotypes derived from breeding. However, it is difficult to rule out, although not yet demonstrated, the role of mutagenic factors related to intensive culture conditions in the emergence of new diseases caused by F. oxysporum. Local appearance of race 3 from race 2 population within $F$. oxysporum f. sp. lycopersici in California underlines such possibility (Cai et al. 2003). The frequency of the occurrence of horizontal gene transfer as a factor of the evolution of $F$. oxysporum pathogenicity is not known but is probably low. However, given the natural inoculum density of this fungus in the soil and rhizosphere of many plants around the world, the process may not be anecdotal and may thus contribute to the emergence of new diseases caused by $F$. oxysporum, whether new formae speciales or new races within these formae speciales.

What farmers need most is early diagnostic tools. For some soilborne diseases, quantifying the infectious potential of soils helps to decide whether or not growing the host plant is possible. These measures are not applicable in the case of diseases caused by F. oxysporum (Alabouvette et al. 2006). This is why molecular tools to detect the presence and activity of pathogenic $F$. oxysporum isolates are needed. These tools must be able to discriminate between races and formae speciales, but also to distinguish them from nonpathogenic forms that are putative biocontrol agents. Recent comparative analysis of $F$. oxysporum genomes provided information on the genome organization and on the genomic region that governs pathogenicity (Ma et al. 2010, 2013). Genomic comparison of whole formae speciales genomes revealed that the effector repertoire of each forma specialis likely determines host specificity (van Dam et al. 2016, 2018). Such studies provide promising insights into the diversity and evolution of $F$. oxysporum pathogenicity. Future large-scale projects aimed at sequencing whole $F$. oxysporum genomes will assuredly improve host range identification and disease management. By combining the promising progress of genomics in characterizing the pathogenic effectors of each $F$. oxysporum forma specialis and race, and the potential of molecular techniques that are constantly evolving, a concrete and feasible challenge will be to develop diagnostic tools to preventively detect the risk of infection by $F$. oxysporum for a given crop and then to take the appropriate measures.

\section{ACKNOWLEDGMENTS}

We thank C. Steinberg who supervised the writing of this review and D. Millot for her effective assistance in searching documents including original scientific articles.

\section{LITERATURE CITED}

Abawi, G. S., and Lorbeer, J. W. 1972. Several aspects of the ecology and pathology of Fusarium oxysporum f. sp. cepae. Phytopathology 62: 870-876.

Aguayo, J., Mostert, D., Fourrier-Jeandeal, C., Cerf-Wendling, I., Hostachy, B., Viljoen, A., and Ioos, R. 2017. Development of hydrolysis probe-based real-time assay for the detection of tropical strains of Fusarium oxysporum f. sp. cubense race 4. PLoS One 12:e0171767.

Alabouvette, C., Raaijmakers, J., De Boer, W., Notz, R., Défago, G., Steinberg, C., and Lemanceau, P. 2006. Concepts and methods to assess the 
phytosanitary quality of soils. Pages 257-270 in: Plant-Microbe Interactions and Soil Quality Handbook. J. Bloem, D. W. Hopkins, and A. Benedetti, eds. CABI Publishing, Wallingford, UK.

Alexander, L. J., and Tucker, C. M. 1945. Physiologic specialization in the tomato wilt fungus Fusarium oxysporum f. lycopersici. J. Agric. Res. 70: 303-313.

Alves-Santos, F. M., Cordeiro-Rodrigues, L., Sayagués, J. M., MartinDominguez, R., Garcia-Benavides, P., Crespo, M. C., Diaz-Minguez, J. M., and Eslava, A. P. 2002. Pathogenicity and race characterization of Fusarium oxysporum f. sp. phaseoli isolates from Spain and Greece. Plant Pathol. 51: 605-611.

Armstrong, G. M., and Armstrong, J. K. 1952. Physiological races of the Fusaria causing wilts of the Cruciferae. Phytopathology 42:255-257.

Armstrong, G. M., and Armstrong, J. K. 1968. Formae speciales and races of Fusarium oxysporum causing a tracheomycosis in the syndrome of disease. Phytopathology 58:1242-1246.

Armstrong, G. M., and Armstrong, J. K. 1981. Formae speciales and races of Fusarium oxysporum causing wilt diseases. Pages 391-399 in: Fusarium: Disease, Biology, and Taxonomy. P. E. Nelson, T. A. Toussoun, and R. J. Cook, eds. The Pennsylvania State University Press, University Park, London.

Baayen, R. P., Förch, M. G., Waalwijk, C., Bonants, P. J. M., Löffler, H. J. M., and Roebroeck, E. J. A. 1998. Pathogenic, genetic and molecular characterisation of Fusarium oxysporum f. sp. lilii. Eur. J. Plant Pathol. 104: 887-894

Baayen, R. P., O’Donnell, K., Bonants, P. J. M., Cigelnik, E., Kroon, L. P. N. M., Roebroeck, E. J. A., and Waalwijk, C. 2000. Gene genealogies and AFLP analyses in the Fusarium oxysporum complex identify monophyletic and nonmonophyletic formae speciales causing wilt and rot disease. Phytopathology 90:891-900.

Baker, K. F. 1948. Fusarium wilt of garden stock (Mathiola incana). Phytopathology 38:399-403.

Beccari, G., Covarelli, L., Balmas, V., and Tosi, L. 2010. First report of Miscanthus $\times$ giganteus rhizome rot caused by Fusarium avenaceum, Fusarium oxysporum and Mucor hiemalis. Australas. Plant Dis. Notes 5: 28-29.

Bloomberg, W. 1971. Disease of Douglas-fir seedlings caused by Fusarium oxysporum. Phytopathology 61:467-470.

Boari, A., and Vurro, M. 2004. Evaluation of Fusarium spp. and other fungi as biological control agents of broomrape (Orobanche ramosa). Biol. Control 30:212-219.

Boerema, G. H., and Hamers, M. E. C. 1988. Check-list for scientific names of common parasitic fungi. Series 3a: Fungi on bulbs: Liliaceae. Netherl. J. Plant Pathol. 94(suppl.):1-32.

Boerema, G. H., and Hamers, M. E. C. 1989. Check-list for scientific names of common parasitic fungi. Series 3a: Fungi on bulbs: Amaryllidaceae and Iridaceae. Netherl. J. Plant Pathol. 95:3.

Bohn, G. W., and Tucker, C. M. 1939. Immunity to Fusarium wilt in the tomato. Science 89:603-604.

Bosland, P. W., and Williams, P. H. 1987. An evaluation of Fusarium oxysporum from crucifers based on pathogenicity, isozyme polymorphism, vegetative compatibility, and geographic origin. Can. J. Bot. 65:2067-2073.

Brayford, D. 1996. Fusarium oxysporum f. sp. cepae. Mycopathologia 133: $39-40$.

Burgess, L. W. 1981. General Ecology of the Fusaria. Pages 225-235 in: Fusarium: Diseases, Biology and Taxonomy. P. E. Nelson, T. A. Toussoun, and R. J. Cook, eds. The Pennsylvania State University Press, University Park, London.

Cai, G., Rosewich Gale, L., Schneider, R. W., Kistler, H. C., Davis, R. M., Elias, K. S., and Miyao, E. M. 2003. Origin of race 3 of Fusarium oxysporum f. sp. lycopersici at a single site in California. Phytopathology 93: 1014-1022.

Canizares, M. C., Gomez-Lama, C., Garcia-Pedrajas, M. D., and Péres-Artés, E. 2015. Study of phylogenetic relationships among Fusarium oxysporum $\mathrm{f}$. sp. dianthi isolates: Confirmation of intrarace diversity and development of a practical tool for simple population analyses. Plant Dis. 99:780-787.

Chalvet, F., Grimaldi, C., Kaper, F., Langin, T., and Daboussi, M.-J. 2003. Hop, an active mutator-like element in the genome of the fungus Fusarium oxysporum. Mol. Biol. Evol. 20:1362-1375.

Chiocchetti, A., Sciaudone, L., Durando, F., Garibaldi, A., and Migheli, Q. 2001. PCR detection of Fusarium oxysporum f. sp. basilici on basil. Plant Dis. 85:607-611.

Daboussi, M.-J., and Capy, P. 2003. Transposable elements in filamentous fungi. Annu. Rev. Microbiol. 57:275-299.

Dean, R., van Kan, J. A. L., Pretorius, Z. A., Hammond-Kosack, K. E., Di Pietro, A., Spanu, P. D., Rudd, J. J., Dickman, M., Kahmann, R., Ellis, J., and Foster, G. D. 2012. The top 10 fungal pathogens in molecular plant pathology. Mol. Plant Pathol. 13:414-430.
Edel, V., Steinberg, C., Gautheron, N., Recorbet, G., and Alabouvette, C. 2001. Genetic diversity of Fusarium oxysporum populations isolated from different soils in France. FEMS Microbiol. Ecol. 36:61-71.

Edel-Hermann, V., Gautheron, N., Mounier, A., and Steinberg, C. 2015. Fusarium diversity in soil using a specific molecular approach and a cultural approach. J. Microbiol. Methods 111:64-71.

Edel-Hermann, V., Gautheron, N., and Steinberg, C. 2012. Genetic diversity of Fusarium oxysporum and related species pathogenic on tomato in Algeria and other Mediterranean countries. Plant Pathol. 61:787-800.

Elzein, A., Brändle, F., Cadisch, G., Kroschel, J., Marley, P., and Thines, M. 2008. Fusarium oxysporum strains as potentiel Striga mycoherbicides: Molecular characterization and evidence for a new forma specialis. Open Mycol. J. 2:89-93.

Epstein, L., Kaur, S., Chang, P. L., Carrasquilla-Garcia, N., Lyu, G., Cook, D. R., Subbarao, K. V., and O'Donnell, K. 2017. Races of the celery pathogen Fusarium oxysporum f. sp. apii are polyphyletic. Phytopathology 107:463-473.

Eriksson, J. 1894. Ueber dia specialisirung des parasitismus bei den Getreiderostpilzen. Ber. Deutsch. Bot. Ges. 12:292-331.

Fernandez, D., Ouinten, M., Tantaoui, A., Geiger, J.-P., Daboussi, M.-J., and Langin, T. 1998. Fot 1 insertions in the Fusarium oxysporum f. sp. albedinis genome provide diagnostic PCR targets for detection of the date palm pathogen. Appl. Environ. Microbiol. 64:633-636.

Fourie, G., Steenkamp, E. T., Gordon, T. R., and Viljoen, A. 2009. Evolutionary relationships among the Fusarium oxysporum f. sp. cubense vegetative compatibility groups. Appl. Environ. Microbiol. 75:47704781.

Fraser-Smith, S., Czislowski, E., Meldrum, R. A., Zander, M., O’Neill, W., Balali, G. R., and Aitken, E. A. B. 2014. Sequence variation in the putative effector gene SIX8 facilitates molecular differentiation of Fusarium oxysporum f. sp. cubense. Plant Pathol. 63:1044-1052.

Geiser, D. M., Jiménez-Gasco, M. M., Kang, S., Makalowska, I., Veeraraghavan, N., Ward, T. J., Zhang, N., Kuldau, G. A., and O'Donnell, K. 2004. FUSARIUM-ID v. 1.0: A DNA sequence database for identifying Fusarium. Eur. J. Plant Pathol. 110:473-479.

Gerlagh, M., and Blok, W. J. 1988. Fusarium oxysporum f. sp. cucurbitacearum n.f. embracing all formae speciales of $F$. oxysporum attacking Cucurbitaceous crops. Netherl. J. Plant Pathol. 94:17-31.

Gilardi, G., Franco Ortega, S., van Rijswick, P. C. J., Ortu, G., Gullino, M. L., and Garibaldi, A. 2017. A new race of Fusarium oxysporum f. sp. lactucae of lettuce. Plant Pathol. 66:677-688.

Gordon, T. R. 2017. Fusarium oxysporum and the Fusarium wilt syndrome. Annu. Rev. Phytopathol. 55:23-39.

Gordon, T. R., and Martyn, R. D. 1997. The evolutionary biology of Fusarium oxysporum. Annu. Rev. Phytopathol. 35:111-128.

Gordon, T. R., Swett, C. L., and Wingfield, M. J. 2015. Management of Fusarium diseases affecting conifers. Crop Prot. 73:28-39.

Gordon, W. L. 1965. Pathogenic strains of Fusarium oxysporum. Can. J. Bot. 43:1309-1318

Habgood, R. M. 1970. Designation of physiological races of plant pathogens. Nature 227:1268-1269.

Hill, A. L., Reeves, P. A., Larson, R. L., Fenwick, A. L., Hanson, L. E., and Panella, L. 2011. Genetic variability among isolates of Fusarium oxysporum from sugar beet. Plant Pathol. 60:496-505.

Imazaki, I., and Kadota, I. 2015. Molecular phylogeny and diversity of Fusarium endophytes isolated from tomato stems. FEMS Microbiol. Ecol. 91:fiv098.

Inami, K., Kashiwa, T., Kawabe, M., Onokubo-Okabe, A., Ishikawa, N., Pérez, E. R., Hozumi, T., Caballero, L. A., Caceres de Baldarrago, F., Jiménez Roco, M., Maladi, K. A., Peever, T. L., Teraoka, T., Kodama, M., and Arie, T. 2014. The tomato wilt fungus Fusarium oxysporum f. sp. lycopersici shares common ancestors with nonpathogenic $F$. oxysporum isolated from wild tomatoes in the Peruvian Andes. Microbes Environ. 29:200-210.

Jarvis, W. R., and Shoemaker, R. A. 1978. Taxonomic status of Fusarium oxysporum causing foot and root rot of tomato. Phytopathology 68: $1679-1680$.

Jiménez-Gasco, M. M., and Jiménez-Díaz, R. M. 2003. Development of a specific polymerase chain reaction-based assay for the identification of Fusarium oxysporum f. sp. ciceris and its pathogenic races $0,1 \mathrm{~A}, 5$, and 6 . Phytopathology 93:200-209.

Joffe, A. Z., and Palti, J. 1977. Species of Fusarium found in uncultivated desert-type soils in Israel. Phytoparasitica 5:119-121.

Jonkers, W., Rodrigues, C. D. A., and Rep, M. 2009. Impaired colonization and infection of tomato roots by the $\Delta$ frpl mutant of Fusarium oxysporum correlates with reduced CWDE gene expression. Mol. Plant-Microbe Interact. 22:507-518.

Katan, T. 1999. Current status of vegetative compatibility groups in Fusarium oxysporum. Phytoparasitica 27:51-64. 
Kendrick, J. B. 1930. Kale yellows in California, caused by Fusarium conglutinans Wollenw. Hilgardia 5:1-15.

Kendrick, J. B., and Snyder, W. C. 1942. Fusarium wilt of radish. Phytopathology 32:1031-1033.

Kistler, H. C. 1997. Genetic diversity in the plant-pathogenic fungus Fusarium oxysporum. Phytopathology 87:474-479.

Kistler, H. C., Alabouvette, C., Baayen, R. P., Bentley, S., Brayford, D., Coddington, A., Correll, J., Daboussi, M.-J., Elias, K., Fernandez, D., Gordon, T. R., Katan, T., Kim, H. G., Leslie, J. F., Martyn, R. D., Migheli, Q., Moore, N. Y., O'Donnell, K., Ploetz, R. C., Rutherford, M. A., Summerell, B., Waalwijk, C., and Woo, S. 1998. Systematic numbering of vegetative compatibility groups in the plant pathogenic fungus Fusarium oxysporum. Phytopathology 88:30-32.

Kommedahl, T., Abbas, H. K., Burnes, P. M., and Mirocha, C. J. 1988. Prevalence and toxigenicity of Fusarium species from soils of Norway near the Arctic Circle. Mycologia 80:790-794.

Koyyappurath, S., Atuahiva, T., Le Guen, R., Batina, H., Le Squin, S., Gautheron, N., Edel-Hermann, V., Peribe, J., Jahiel, M., Steinberg, C., Liew, E. C. Y., Alabouvette, C., Besse, P., Dron, M., Sache, I., Laval, V., and Grisoni, M. 2015. Fusarium oxysporum f. sp. radicis-vanillae is the causal agent of root and stem rot of vanilla. Plant Pathol. 65:612-625.

Lecomte, C. 2016. Fusariose du cyclamen: Détection préventive et contrôle biologique. Ph.D. Thesis, University of Burgundy, Dijon, France.

Lecomte, C., Edel-Hermann, V., Cannesan, M. A., Gautheron, N., Langlois, A., Alabouvette, C., Robert, F., and Steinberg, C. 2016. Fusarium oxysporum f. sp. cyclaminis: Underestimated genetic diversity. Eur. J. Plant Pathol. 145:421-431.

Li, E., Wang, G., Xiao, J., Ling, J., Yang, Y., and Xie, B. 2016. A SIX1 homolog in Fusarium oxysporum f. sp. conglutinans is required for full virulence on cabbage. PLoS One 11:e0152273.

Li, Y., Garibaldi, A., and Gullino, M. L. 2010. Genetic variability analysis and molecular detection of Fusarium oxysporum f. sp. eustomae isolated from Eustoma grandiflorum in northern Italy. J. Phytopathol. 158:546-553.

Lievens, B., Claes, L., Vakalounakis, D. J., Vanachter, A. C. R. C., and Thomma, B. P. H. J. 2007. A robust identification and detection assay to discriminate the cucumber pathogens Fusarium oxysporum f. sp. сисиmerinum and f. sp. radicis-cucumerinum. Environ. Microbiol. 9:2145-2161.

Lievens, B., Rep, M., and Thomma, B. P. H. J. 2008. Recent developments in the molecular discrimination of formae speciales of Fusarium oxysporum. Pest Manag. Sci. 64:781-788.

Lievens, B., van Baarlen, P., Verreth, C., van Kerckhove, S., Rep, M., and Thomma, B. P. H. J. 2009. Evolutionary relationships between Fusarium oxysporum $\mathrm{f}$. sp. lycopersici and $F$. oxysporum f. sp. radicis-lycopersici isolates inferred from mating type, elongation factor-1 alpha and exopolygalacturonase sequences. Mycol. Res. 113:1181-1191.

Luongo, L., Vitale, S., Haegi, A., and Belisario, A. 2012. Development of SCAR markers and PCR assay for Fusarium oxysporum f. sp. melonis race 2-specific detection. J. Plant Pathol. 94:193-199.

Ma, L.-J. 2014. Horizontal chromosome transfer and rational strategies to manage Fusarium vascular wilt diseases. Mol. Plant Pathol. 15: 763-766.

Ma, L.-J., Geiser, D. M., Proctor, R. H., Rooney, A. P., O’Donnell, K., Trail, F., Gardiner, D. M., Manners, J. M., and Kazan, K. 2013. Fusarium pathogenomics. Annu. Rev. Microbiol. 67:399-416.

Ma, L.-J., van der Does, H. C., Borkovich, K. A., Coleman, J. J., Daboussi, M.-J., and Di Pietro, A. 2010. Comparative genomics reveals mobile pathogenicity chromosomes in Fusarium. Nature 464:367-373.

Mandeel, Q. A., Abbas, J. A., and Saeed, A. M. 1995. Survey of Fusarium species in an arid environment of Bahrain II. Spectrum of species on five isolation media. Sydowia 47:223-239.

Manici, L. M., and Cerato, C. 1994. Pathogenicity of Fusarium oxysporum f. sp. tuberosi isolates from tubers and potato plants. Potato Res. 37:129-134.

Michielse, C. B., van Wijk, R., Reijnen, L., Cornelissen, B. J. C., and Rep, M. 2009a. Insight into the molecular requirements for pathogenicity of Fusarium oxysporum f. sp. lycopersici through large-scale insertional mutagenesis. Genome Biol. 10:R4.

Michielse, C. B., van Wijk, R., Reijnen, L., Manders, E. M. M., Boas, S., Olivain, C., Alabouvette, C., and Rep, M. 2009b. The nuclear protein Sge1 of Fusarium oxysporum is required for parasitic growth. PLoS Pathog. 5:e1000637.

Nelson, P. E., Toussoun, T. A., and Cook, R. J. 1981. Fusarium: Diseases, Biology and Taxonomy. The Pennsylvania State University Press, University Park, London.

O'Donnell, K., and Cigelnik, E. 1997. Two divergent intragenomic rDNA ITS2 types within a monophyletic lineage of the fungus Fusarium are nonorthologous. Mol. Phylogenet. Evol. 7:103-116.

O’Donnell, K., Gueidan, C., Sink, S., Johnston, P. R., Crous, P. W., and Glenn, A. 2009. A two-locus DNA sequence database for typing plant and human pathogens within the Fusarium oxysporum species complex. Fungal Genet. Biol. 46:936-948

O'Donnell, K., Kistler, H. C., Cigelnik, E., and Ploetz, R. C. 1998. Multiple evolutionary origins of the fungus causing Panama disease of banana: Concordant evidence from nuclear and mitochondrial gene genealogies. Proc. Natl. Acad. Sci. 95:2044-2049.

O’Donnell, K., Rooney, A. P., Proctor, R. H., Brown, D. W., McCormick, S. P., Ward, T. J., Frandsen, J. N., Lysøe, E., Rehner, S. A., Aoki, T., Robert, V. A. R. G., Crous, P. W., Groenewald, J. Z., Kang, S., and Geiser, D. M. 2013. Phylogenetic analyses of $R P B 1$ and $R P B 2$ support a middle Cretaceous origin for a clade comprising all agriculturally and medically important fusaria. Fungal Genet. Biol. 52:20-31.

O’Donnell, K., Sutton, D., Rinaldi, M. G., Sarver, B. A. J., Arunmozhi Balajee, S., Schroers, H.-J., Summerell, R. C., Robert, V. A. R. G., Crous, P. W., Zhang, N., Aoki, T., Jung, K., Park, J., Lee, Y.-H., Kang, S., Park, B., and Geiser, D. M. 2010. Internet-accessible DNA sequence database for identifying Fusaria from human and animal infections. J. Clin. Microbiol. 48:3708-3718.

O’Donnell, K., Ward, T. J., Robert, V. A. R. G., Crous, P. W., Geiser, D. M., and Kang, S. 2015. DNA sequence-based identification of Fusarium: Current status and future directions. Phytoparasitica 43:583-595.

Olivain, C., and Alabouvette, C. 1999. Process of tomato root colonization by a pathogenic strain of Fusarium oxysporum f. sp. lycopersici in comparison with a non-pathogenic strain. New Phytol. 141:497-510.

Ortu, G., Bertetti, D., Gullino, M. L., and Garibaldi, A. 2013. A new forma specialis of Fusarium oxysporum on Crassula ovata. J. Plant Pathol. 95: 33-39.

Ortu, G., Bertetti, D., Gullino, M. L., and Garibaldi, A. 2018. Fusarium oxysporum f. sp. lavandulae, a novel forma specialis causing wilt on Lavandula $\times$ allardii. J. Plant Pathol. 100:391-397.

Palmero, D., Rubio-Moraga, A., Galvez-Patón, L., Nogueras, J., Abato, C., Gómez-Gómez, L., and Ahrazem, O. 2014. Pathogenicity and genetic diversity of Fusarium oxysporum isolates from corms of Crocus sativus. Ind. Crops Prod. 61:186-192.

Park, B., Park, J., Cheong, K.-C., Choi, J., Jung, K., Kim, D., Lee, Y.-H., Ward, T. J., O'Donnell, K., Geiser, D. M., and Kang, S. 2011. Cyber infrastructure for Fusarium: Three integrated platforms supporting strain identification, phylogenetics, comparative genomics and knowledge sharing. Nucleic Acids Res. 39:D640-D646.

Pasquali, M., Dematheis, F., Gullino, M.-L., and Garibaldi, A. 2007. Identification of race 1 of Fusarium oxysporum $\mathrm{f}$. sp. lactucae on lettuce by interretrotransposon sequence-characterized amplified region technique. Phytopathology 97:987-996.

Pastrana, A. M., Kirkpatrick, S. C., Kong, M., Broome, J. C., and Gordon, T. R. 2017. Fusarium oxysporum f. sp. mori, a new forma specialis causing Fusarium wilt of blackberry. Plant Dis. 101:2066-2072.

Ploetz, R. C. 2006. Fusarium wilt of banana is caused by several pathogens referred to as Fusarium oxysporum f. sp. cubense. Phytopathology 96: 653-656.

Ploetz, R. C. 2015. Fusarium wilt of banana. Phytopathology 105:1512-1521.

Poli, A., Gilardi, G., Spadaro, D., Gullino, M. L., and Garibaldi, A. 2012. Molecular characterization of Fusarium oxysporum f. sp. cichorii pathogenic on chicory (Cichorium intybus). Phytoparasitica 40:383-391.

Polizzi, G., and Vitale, A. 2004. First report of basal stem rot of golden barrel cactus caused by Fusarium oxysporum f. sp. opuntiarum in Italy. Plant Dis. 88:85.

Pound, G. S., and Fowler, D. L. 1951. A Fusarium wilt of radish in Wisconsin. Phytopathology 41:30.

Puhalla, J. E. 1985. Classification of strains of Fusarium oxysporum on the basis of vegetative compatibility. Can. J. Bot. 63:179-183.

Rep, M., van der Does, H. C., Meijer, M., van Wijk, R., Houterman, P. M., Dekker, H. L., de Koster, C. G., and Cornelissen, B. J. C. 2004. A small, cysteine-rich protein secreted by Fusarium oxysporum during colonization of xylem vessels is required for I-3-mediated resistance in tomato. Mol. Microbiol. 53:1373-1383.

Risser, G., Banihashemi, Z., and Davis, D. W. 1976. A proposed nomenclature of Fusarium oxysporum f. sp. melonis races and resistance genes in Cucumis melo. Phytopathology 66:1105-1106.

Roebroeck, E. J. A. 2000. Fusarium oxysporum from iridaceous crops: Analysis of genetic diversity and host specialisation. Ph.D. Thesis, University of Amsterdam, The Netherlands.

Seifert, K. A. 2009. Progress towards DNA barcoding of fungi. Mol. Ecol. Resour. 9:83-89.

Snyder, W. C., and Hansen, H. N. 1940. The species concept in Fusarium. Am. J. Bot. 27:64-67.

Sousa, M. V., Machado, J. da C., Simmons, H. E., and Munkvold, G. P. 2015. Real-time quantitative PCR assays for the rapid detection and quantification 
of Fusarium oxysporum f. sp. phaseoli in Phaseolus vulgaris (common bean) seeds. Plant Pathol. 64:478-488.

Stakman, E. C. 1913. A study in cereal rusts: Physiological races. Thesis, University of Minnesota.

Stakman, E. C., Stewart, D. M., and Loegering, W. Q. 1962. Identification of physiologic races of Puccinia graminis var. tritici. U.S. Department of Agriculture, Agricultural Research Service.

Steinberg, C., Lecomte, C., Alabouvette, C., and Edel-Hermann, V. 2016. Root interactions with non-pathogenic Fusarium oxysporum. Hey Fusarium oxysporum, what do you do in life when you do not infect a plant? Pages 281-299 in: Belowground Defence Strategies in Plants. C. M. Vos and K. Kazan, eds. Springer International Publishing, Switzerland.

Stewart, J. E., Abdo, Z., Dumroese, R. K., Klopfenstein, N. B., and Kim, M.-S. 2012. Virulence of Fusarium oxysporum and $F$. commune to Douglas-fir (Pseudotsuga menziesii) seedlings. For. Pathol. 42:220-228.

Taylor, A., Vagany, V., Jackson, A. C., Harrison, R. J., Rainoni, A., and Clarkson, J. P. 2016. Identification of pathogenicity-related genes in Fusarium oxysporum f. sp. cepae. Mol. Plant Pathol. 17:1032-1047.
Trujillo, E. E. 1963. Fusarium yellows and rhizome rot of common ginger. Phytopathology 53:1370.

Vakalounakis, D. J. 1996. Root and stem rot of cucumber caused by Fusarium oxysporum f. sp. radicis-cucumerinum f. sp. nov. Plant Dis. 80:313-316.

Vakalounakis, D. J., Doulis, A. G., and Klironomou, E. 2005. Characterization of Fusarium oxysporum f. sp. radicis-cucumerinum attacking melon under natural conditions in Greece. Plant Pathol. 54:339-346.

van Dam, P., de Sain, M., ter Horst, A., van der Gragt, M., and Rep, M. 2018. Use of comparative genomics-based markers for discrimination of host specificity in Fusarium oxysporum. Appl. Environ. Microbiol. 84:e01868-17.

van Dam, P., Fokkens, L., Schmidt, S. M., Linmans, J. H. J., Kistler, H. C., Ma, L.-J., and Rep, M. 2016. Effector profiles distinguish formae speciales of Fusarium oxysporum. Environ. Microbiol. 18:4087-4102.

Weimer, J. L. 1944. Some root rots and a foot rot of lupines in the Southeastern part of the United States. J. Agric. Res. 68:441-457.

Zhou, X. G., Everts, K. L., and Bruton, B. D. 2010. Race 3, a new and highly virulent race of Fusarium oxysporum f. sp. niveum causing Fusarium wilt in watermelon. Plant Dis. 94:92-98. 